\title{
Efficiency and Goals of Smallholder Sugarcane Farmers in Eswatini (Swaziland)
}

\author{
Douglas Kibirige (Corresponding Author), Ajay S. Singh \\ Department of AEM, Faculty of Agriculture, University of Eswatini, Luyengo M205, \\ Eswatini (Swaziland)
}

Received: May 10, 2021 Accepted: June 21, 2021 Published: June 22, 2021

doi:10.5296/jas.v9i3.18776

URL: https://doi.org/10.5296/jas.v9i3.18776

\begin{abstract}
Establishing farmers' goals is very essential for increased productivity and profitability in sugarcane production. This study aimed at establishing farmers' goals and their relationship with farmers' efficiency. The study used primary data collected from 147smallholder sugarcane farmers. This study employed factor analysis to generate goal orientations of farmers and estimated farmers' efficiency using Data Envelopment Analysis (DEA) model. The findings of the study revealed that the majority of the farmers interviewed were females $(57 \%)$, with $39 \%$ of farmers' attained secondary education, average mean age of 56 years, farming experience of 10 years and cultivate about 4.5 hectares of sugarcane. Farmers' goal orientations generated were instrumental orientation, sustainable orientation, family and leisure orientation, expressive orientation and social status orientation. Farmers' estimated technical efficiency, allocative efficiency and economic efficiency were $89.57 \%, 84.94 \%$ and $76.43 \%$, respectively. The results suggest that farmers can still improve efficiencies without changing the available technologies. The drivers of farmers' technical efficiency were education, age, instrumental orientation and social status. Farmers' allocative efficiency was influenced by age, family and leisure orientation and social status orientation. The determinants of farmers' economic efficiency were education, family and leisure orientation, age and social status orientation. The study recommends formulating rural development programmes and policies that target sugarcane farmers' engagement and participation in sugarcane production and also consider farmers' oriented goals and socio-economic drivers for significant increase in productivity.
\end{abstract}

Keywords: goals and efficiency, principal component, smallholder sugarcane farmers

\section{Introduction}

\subsection{Swaziland Sugar Industry}

The Swaziland sugar industry is the largest industry in Swaziland and plays a significant role 
in the Swaziland economy. The Swaziland sugar industry constitutes a variety of participants which are the Swaziland Sugar Association, millers and cane growers. The sugar industry is regulated by the Sugar Act of 1967 (Dlamini et al., 2010; Esterhuizen \& Pickelsimer, 2014; SSA, 2015). Sugarcane production in Swaziland started in Big Bend as early as 1956 and has been based on sugarcane estates owned by the millers until in 1962 when 257 smallholder farmers started to produce under the Vuvulane irrigation (Dlamini \& Masuku, 2012; Dlamini \& Dlamini, 2012; Terry \& Ogg, 2016). In 1991, the Swaziland Sugar Association (SSA) and the Swaziland Government set aside 10000 tonnes of sugar quota and provided technical assistance for smallholder farmers who produced sugarcane individually and as farmer companies (Dlamini et al., 2010; Dlamini \& Masuku, 2012; Terry \& Ogg, 2016). To further expand the sugar industry, Komati Downstream Development Project (KDDP) and Lower Usuthu Smallholder Irrigation Project (LUSIP) were established in 2000 and 2003, respectively (Simelane, 2014; SSA, 2015; Terry \& Ogg, 2016). The area under sugarcane increased as more smallholder farmers were involved in sugarcane production and access to irrigation increased through significant investments by the Swaziland government and private organizations. Although, the sugar industry largely depended upon large scale production (77 per cent of production in 2012/13), the involvement of smallholders producers enabled the area under sugarcane to increase by 28 per cent from 2000 to 2013 (Esterhuizen \& Pickelsimer, 2014; Terry \& Ogg, 2016). Of the total area under sugarcane over 23\% (14000 hectares) was under the smallholder sugarcane growing sector in 2014/15 growing season and yielded 685000 tonnes (Crawford, 2014; SSA, 2015).

The Swaziland sugar industry contributes to rural development and poverty initiatives by providing social services infrastructure, income and transforming subsistence farming to commercial farming (Crawford, 2014; Liversage \& Jonckheere, 2014). In 2014/15, the sugar industry accounted for $74 \%$ of total agricultural output and had contributed $16 \%$ of the total export earnings, $17 \%$ and $10 \%$ of the private and national wage employment, respectively, and $25 \%$ to the total manufacturing output and $13 \%$ to Gross Domestic Product (GDP). The revenue generated from export of sugar to European Union (EU) countries, Southern African Union Customs (SACU), Tripartite Free Trade Area (TFTA) and World markets would be shared between sugarcane growers and millers (SSA, 2015). The Government of Swaziland, through Chiefs and Swaziland Water and Agricultural Development Enterprise (SWADE), has made commendable efforts to increase the area under sugarcane production by establishing developmental projects (Liversage \& Jonckheere, 2014). For instance, sugarcane acreage increased from about 52800 hectares in 2009/10 to 61000 hectares in 2014/2015. Due to increase in area under sugarcane there was a progressive increase in quantity of both sugarcane and sugar produced per annum from 2009/10 to 2014/15. However, average sucrose percentage and yield per hectare had been fluctuating from 2009/10 to 2014/15 with yield per hectare declining from 2011/12 to 2014/15 (see Table 1).

Although, recently land in the Lower Usuthu Smallholder Irrigation Project (LUSIP) and Komati Downstream Development Project (KDDP) areas were given to smallholder farmers to increase sugarcane production and alleviate rural poverty, an increase in production costs were impacting negatively on profitability and sustainability (Simelane, 2014; SSA, 2015). 
Climate change and variability posed a threat to the sugarcane crop, even though Swaziland has 4.5 billion cubic meters of renewable water resources available with $23 \%$ withdrawn annually, of which most (97\%) of the water withdrawn is used for irrigation of sugarcane land currently (Food and Agriculture Organisation (FAO), 2013; SSA, 2015). Despite an increase in the sugarcane production area by about 1.4 percent, there was a decrease in yield per hectare per annum of about one percent in 2014/15 (SSA, 2015). Sugarcane productivity is greatly affected by, among other factors, labour, basal fertilizer, top dressing fertilizer and land size (Dlamini \& Masuku, 2012; SSA, 2015).

Table 1. Sugarcane production trends in Swaziland

\begin{tabular}{l|l|l|l|l|l|l}
\hline Aspect & $\mathbf{2 0 0 9 / 1 0}$ & $\mathbf{2 0 1 0 / 1 1}$ & $\mathbf{2 0 1 1 / 1 2}$ & $\mathbf{2 0 1 2 / 1 3}$ & $\mathbf{2 0 1 3 / 1 4}$ & $\mathbf{2 0 1 4 / 1 5}$ \\
\hline $\begin{array}{l}\text { Total land (Ha) } \\
\text { Yield/Ha (tonnes) }\end{array}$ & 52822 & 53376 & 54876 & 57103 & 58979 & 59795 \\
\hline $\begin{array}{l}\text { Cane production } \\
\text { (tonnes) }\end{array}$ & 4908000 & 4862000 & 5456000 & 5662000 & 5640096 & 6000000 \\
\hline $\begin{array}{l}\text { Average Sucrose (\%) } \\
\text { Sugar (tonnes) }\end{array}$ & 14.32 & 13.9 & 12.76 & 13.97 & 12.5 & 13.68 \\
\hline
\end{tabular}

Source: Crawford (2014), Esterhuizen and Pickelsimer (2014) and SSA (2015)

However, a body of literature suggests that agricultural productivity is influenced by farmers' goals and production efficiency (Padilla-Fernandez \& Nuthall, 2001; Basarir, 2002; Tew, 2010; Dindi, 2013; Kibirige, 2013; Sihlongonyane, 2014; Kibirige et al., 2016). Goals are considered to be specific end states toward which producers hold positive attitudes. Farmers' goals are internal representations of desired outcomes that govern individual and entrepreneurial behaviour. Thus, goals are desired individual endeavours that maximise utility (Padilla-Fernandez \& Nuthall, 2001; Kibirige, 2013). Furthermore, Martz (2006) regarded goals of farming households as ones initiating reaction approach that has a bearing on the operation of the farm enterprise. In fact, famers' goals correspond with agricultural productivity. One measure of success in any agricultural undertaking is whether or not goals are achieved (Fairweather \& Keating, 1990).

Kibirige (2013) documented that, farmers' needs are increased accumulation of household income and assets with less emphasis on the importance of farmers' social values and independence goals related to agricultural production. In fact, farmers' goals are not only for profit maximisation but some farmers may engage in farming in order to augment their lifestyle, social, spiritual and family related aspirations (Pereira, 2011). Moreover, goals are internal representations of desired outcomes, practices, developments and prestigious values rather than for profit (Tew, 2010). Basarir (2002) suggested that goals other than profit 
maximisation compete strongly in farmers' decisions. In addition, Parminter and Perkins (2001) revealed that farmers who put emphasis on goals become competitive. Furthermore, Kibirige (2013) viewed farmers' goals as exerting influence on farmers' decision making strategies of which non-economic goals are a determinant to farmers' level of productive efficiency. However, the ability to measure efficiency depends on the ability to comprehend the farmers' goals and preferences for different values of their right minds to maximise the desired utilities. Therefore, restricting farmers' goals and success to profit maximisation may lead to denunciation and misinterpretation of rural farmers' poor adoption of technologies and undermine rural development programmes (Kibirige et al., 2016). Thus, a goal and productive efficient oriented farmer will use scarce resources objectively and proficiently thereby improving productivity (Pereira, 2011).

Dlamini and Masuku (2012) argued that inefficient accomplishment by smallholder sugarcane farmers in Swaziland is due to inadequate application of fertilizer. Although farmers should apply the optimum levels of fertilizer, factors like high prices and climate change are an adversity for smallholder sugarcane farmers in Swaziland, to produce high excellent yields. Moreover, another challenge was eradication of the EU preferential market where guaranteed Swaziland sugar price was reduced of over 30\% in 2014/15 growing season, of which now it will face the SACU, African/Regional markets which are volatile (Hlophe, 2014; SSA, 2015). Furthermore, Swaziland failed to meet African Growth and Opportunity Act (AGOA) bench marks set by United States of America (USA) and this made Swaziland sugar market currently unattractive in USA (SSA, 2015). In order to safeguard the sugar industry, it is paramount to explore farmers' goals and efficiency so that the government of Swaziland and donors would better forecast on farmers' economic behaviour and comprehend the types of programmes that would interest farmers in order to improve production efficiency.

\subsection{Significance of the Present Study}

The government of Swaziland and donors continuously expand sugarcane growing in the KDDP and LUSIP with commendable efforts of increasing productivity and efficiency (SSA, 2015). Although there is expansion of the area under sugarcane production, there is observable reduction in sucrose content (Dlamini \& Masuku, 2012). In addition, increased input prices are an encroachment to total gross margins of the smallholder sugarcane farmers. Furthermore, the Swazi sugar is at stake due to reduced prices by EU markets and uncertainty in the USA markets as a result of failure by the country to meet AGOA bench marks of which it will compete in the volatile world sugar market (Hlophe, 2014; SSA, 2015).

In order to increase productivity, many studies have recommended the use of tangible resources with less emphasis on intangible resources (Ayaz \& Hussain, 2011; Dlamini \& Masuku, 2012; Ali et al., 2013; Thabethe et al., 2014; Kibirige, 2013). Sugarcane productivity is thought to be boosted through increased amount of inputs, training of farmers and increased use of agro organic and chemical applications (Crawford, 2014). However, the mentioned agro-inputs and farmer training may not be the only factors responsible for increased sugarcane productivity but also intangible factors like farmers' lifestyle, social, 
intrinsic and family goals and technical, allocative and economic efficiency may augment productivity (Fairweather \& Keating, 1990; Padilla-Fernandez \& Nuthall, 2001; Basarir, 2002; Martz, 2006; Tew, 2010; Pereira, 2011; Kibirige, 2013; Kibirige et al., 2016). So far little rigorous work has been undertaken to quantitatively and qualitatively study the influence of goals on efficiency levels with the purpose of identifying ways of improving productive efficiency. The determination of the relationships between goals and efficiency levels, for smallholder sugarcane farmers, will enhance identification of the sources where improvement can be made. The study attempts to fill this gap by examining the technical, allocative and economic efficiencies and goals of the smallholder sugarcane farmers in Swaziland.

It is widely held that production efficiency is at the heart of sugarcane production. This is because the scope of sugarcane production can be expanded and sustained by farmers through efficient use of resources. Production levels and success of a sugarcane farm depends on the input use efficiency and the quality of decisions made by the smallholder farmer (Basarir, 2002; Kalinga, 2014). The concern of having low returns in the sugar industry in Swaziland raises the supposition that poor sugarcane productivity could be increased if smallholder farmers could operate at a full technical, allocative and economic efficiency levels with the existing technologies (Dlamini et al., 2010; Hlophe, 2014; SSA, 2015).

In farming, choices must be made among alternative production activities depending on the priority of smallholder farmers' goals and how individual farmers use existing technologies. It is envisaged that the findings would assist government of Swaziland and private organisations in setting appropriate policies that could enhance the sugar industry to achieve greater production efficiency. A few studies have been undertaken to measure production efficiency of smallholder sugarcane farmers in Swaziland (Dlamini et al., 2010; Dlamini et al., 2012). Therefore, the study sought to close this research gap and the results to be a stepping stone for more research studies thereby improving production efficiency and the Swaziland economy. It is with great presumption that there would be improvement in household income, reduction in poverty and rural development in Swaziland. The main objective of study was to explore smallholder sugarcane farmers' goals and socioeconomic characteristics and their influence on production efficiency in Swaziland. The specific objectives of the study were:

(i) To identify smallholder sugarcane farmers' goals.

(ii) To determine the relationship between smallholder sugarcane farmers' socioeconomic characteristics and their goal orientations.

(iii) To estimate the technical, allocative and economic efficiency of sugarcane farmers

(iv) To establish the influence of smallholder sugarcane farmers' goals and their socioeconomic characteristics on sugarcane production efficiency.

The hypotheses of the study are as follows:

H01: Smallholder sugarcane farmers are not efficient in use of resource. 
H1 1 : Smallholder sugarcane farmers are efficient in use of resource.

$\mathbf{H O}_{2}$ : Socio-economic characteristics of smallholder sugarcane farmers do not significantly influence farmers' production efficiency.

H12: At least one of the socio-economic characteristics of smallholder sugarcane farmers' significantly influences the production efficiency.

\subsection{Theoretical and Conceptual Framework}

Economic theory describes a production function in terms of maximum output that can be produced from a specified set of inputs, given the existing technology available to the farm. Production efficiency reduces production costs and makes a farm more competitive. A farm is considered efficient when it produces at the most excellent production frontier. The most common assumption is that the goal of the producers is profit maximisation. However, it is believed that the objectives and goals of the producer are intertwined with farmers' psychological makeup (Kibirige, 2008). Therefore, this study is based on assumption by Padilla-Fernandez and Nuthall (2001) that producers aim at maximising output subject to existing constraints. Allocative efficiency is application of combination of factors that cause costs to produce a certain amount of products and will lead to maximising profits with the present methods (Sihlongonyane, 2014). Thus, the allocative efficient level of production is where the farm operates at the least cost combination of inputs. Therefore, this study is based on assumption by Padilla-Fernandez and Nuthall (2001) that smallholder producers aim at minimising input subject to existing constraints. Dindi (2013) documented that farmers engage into sugarcane production with a motivation to satisfy certain needs. The factors motivating farmers into sugarcane production can either be within or from the environment.

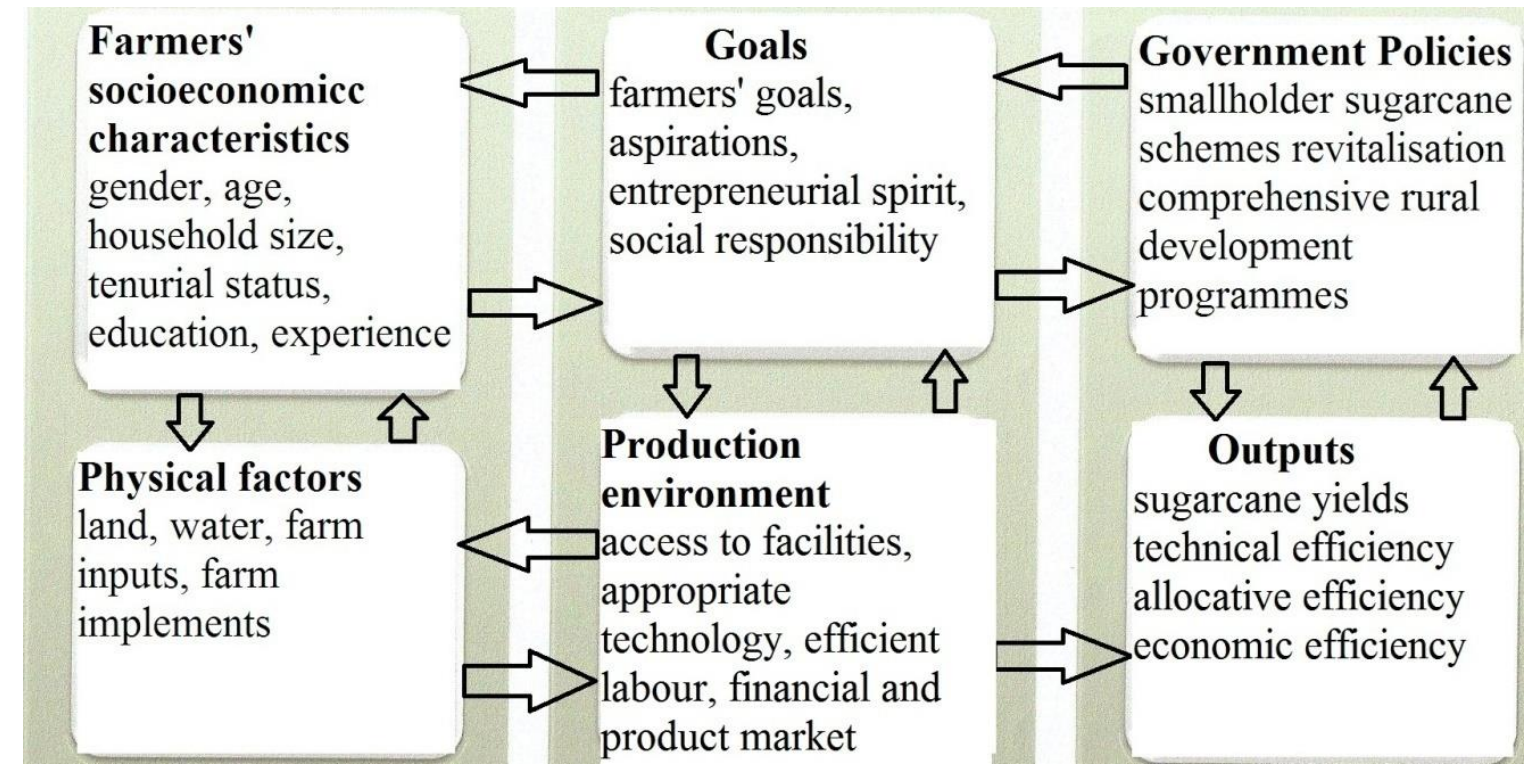

Figure 1. Conceptual framework

Source: Kibirige (2013), Dindi (2013) and Padilla-Fernandez and Nuthall (2001)

Sugarcane production is a dependent variable (productivity) because its production varies as a 
result of the independent variables (goal and value orientations and socioeconomic variables) (Padilla-Fernandez \& Nuthall, 2001). The desire to satisfy the independent variables creates tension in the farmers, and the tension motivates them to be involved in sugarcane farming. Farmers articulate their values through a range of individual farming goals. Therefore, they are more open to transform their existing farming practices. Farmers who consider stimulation and self-esteem values highly were likely to emphasize goals for personal growth and autonomy (Parminter \& Perkins, 2001). Many farmers' behaviours and management styles may be associated with goal orientations.

The conceptual framework in Figure 1 illustrates how government policies can influence the farmers' goals, aspirations, entrepreneurial spirit, sugarcane yields and production efficiency. It is the relative ordering of values orientations which determine how sugarcane farmers decide to act and perform. Farmers aspire to achieve all valued ends except in situations where these are mutually exclusive. The comprehensive rural development programmes provide easy availability and farmer's accessibility to productive assets like land, water and implements which in turn are utilized given a favourable environment for sugarcane production. The environment for sugarcane production is thought to entail appropriate education, efficient financial and product markets, availability of appropriate technologies and efficient and flexible labour markets. The goals for increased sugarcane productivity and production efficiency are influenced by gender, age, tenurial status and experience of the smallholder farmer. Increased yields of smallholder sugarcane farmer is anticipated to improve household wealth and livelihood, improve food security and health, provision of employment and reduce poverty levels among rural communities.

\section{Methodology}

\subsection{Study Area}

The study was conducted in Lubombo region in the southern part of the Eswatini and Hhohho region in the northern part of the Eswatini, currently growing sugarcane on over 11100 and 6500 hectares of irrigated sugarcane, respectively. The study area covered LUSIP and Poortzicht sugarcane farming zones in the south and KDDP and Vuvulane sugarcane growing area in the north (Terry \& Ogg, 2016).

\subsection{Research Design}

The study was a cross sectional research, which used descriptive, qualitative and quantitative research design. The research design endeavoured to determine the relationship between sugarcane inputs (independent variables) and output (dependent variables) and the rating of the importance of farmers' goals.

\subsection{Sampling Method}

Basing on the Swaziland Sugar Association office records, there were 596 individual farmers and 99 farmers' associations who produced sugarcane in 2014/2015, which translates to a sampling frame of 6326 individual farmers. Sample size (147) was determined using formula (Singh \& Masuku, 2014) as shown below: 


$$
\mathrm{n}_{0}=\frac{N}{1+N(e)^{2}}
$$

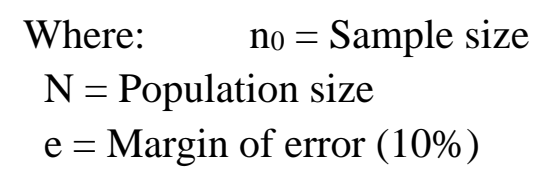

Purposive sampling was applied in selecting Hhohho and Lubombo regions as the sugarcane growing regions. Then smallholder sugarcane farmers were stratified according to individual farmers, farmer associations and milling companies. A sample size of individual farmers and individual farmers from each farmer company was established and randomly selected.

\subsection{Data Collection and Analysis}

Data which included demographic characteristics of the farmers, input and output variables and rating of the importance of the farmers' goals on a 1 to 4 point Likert scale were collected through the use of personal interviews using a structured questionnaire. The collected data were coded and analysed using Statistical Package for Social Sciences (SPSS version 20). Statistical analysis was carried out to produce means, frequencies, standard deviation, minimum and maximum values, and percentages. Factor analysis method was employed to analyse smallholder farmers' goal orientations using the principal component analysis model. Data Envelopment Analysis (DEA) model was used to estimate technical, allocative and economic efficiencies of the smallholder sugarcane farmers at once. An Ordinary Least Square regression (OLS) model was employed in order to analyse the relationship of farmers' socioeconomic characteristics and farmers' goal orientations (principal components) and impact of farmers' goal orientations and socioeconomic characteristics on production efficiency.

\subsection{Analytical Framework and Variable Measurement}

The study used DEA because it effects performance evaluations and inferences directly from observed data with no assumptions. Further, the study used a 4 point Likert scale and rating order to solicit farmers' goals with $1=$ not important to 4 =very important. The goals were clustered into principal components. The principal components were generated using factor analysis and then an average mean score for each component was established (Kibirige, 2013; Pereira, 2011; Padilla-Fernandez \& Nuthall, 2001). An Ordinary Least Square (OLS) regression model was employed in order to ascertain impact of farmers' socioeconomic characteristics on farmers' goal orientations (principal components) as well as influence of farmers' goal orientations and socioeconomic characteristics on efficiency. Farmers' socioeconomic characteristics used are explained in Table 2 based on the hypothesised impact of the extracted principal components of the farmers' orientations and production efficiency level index of smallholder farmers.

Table 2. Empirical model variables and their hypothesised signs 


\begin{tabular}{l|l|l|l}
\hline Variable & Description & Unit & $\begin{array}{l}\text { Hypothesized } \\
\text { sign }\end{array}$ \\
\hline EDUC & Educational level of respondent & years & + \\
\hline EXPE & Farming experience of respondent & years & + \\
\hline AGE & Age of the respondent & years & + \\
\hline HHSZE & Size of household & number & + \\
\hline GNDR & $\begin{array}{l}\text { Gender of the respondent (female }=1, \\
\text { male }=0)\end{array}$ & Dummy variable & + -- \\
\hline OCCUPTN & $\begin{array}{l}\text { Occupation of respondent (farmer }=1, \\
\text { otherwise }=0)\end{array}$ & Dummy variable & + \\
\hline Off-farm & Duration of off-farm work & years & - \\
\hline GOAL 1 & Instrumental orientation & scores & + \\
\hline GOAL 2 & Sustainable orientation & scores & + \\
\hline GOAL 3 & Family and leisure orientation & scores & + \\
\hline GOAL 4 & Expressive orientation & scores & + \\
\hline GOAL 5 & Social status & scores & + \\
\hline
\end{tabular}

\subsection{Data Envelopment Analysis Approach}

Data Envelopment Analysis (DEA) model was used to generate technical, allocative and economic efficiencies using linear programming equations. The DEA model is data oriented as it determined efficiency based on inputs and outputs of a farming entity.

2.6.1 Technical Efficiency

Maximize $\theta \lambda^{\theta}$.

Subject to: $\quad-Y_{\mathrm{ij}}+\mathrm{Y} \lambda \geq 0$

$$
\begin{aligned}
& \theta \mathrm{X}_{\mathrm{ij}}-\mathrm{X} \lambda \geq 0 \\
& \mathrm{~N} 1^{\prime} \lambda=1 \\
& \lambda \geq 0
\end{aligned}
$$

Where: $\theta$ is a scalar, $\mathrm{N} 1$ is an $\mathrm{N} \mathrm{x} 1$ vector of ones and $\lambda$ is an $\mathrm{N} \times 1$ vector of constants. The value of $\theta$ obtained is the Technical Efficiency score for the $\mathrm{j}^{\text {th }}$ farmer and these scores normally lie between zero and one. If $\theta=1$, then the farmer is said to be efficient and lies on the frontier. $\mathrm{X}_{\mathrm{ij}}=$ (transport, amount of water, labour, fertilizer, herbicides, ripeners). $\mathrm{Y}_{\mathrm{ij}}=$ (value of output $\mathrm{i}^{\text {th }}$ and farmer $\mathrm{j}^{\text {th }}$ crop enterprise). 


\subsubsection{Allocative Efficiency}

Allocative efficiency was obtained using DEA. Specific model is given as follows:

Minimize: $\theta \lambda^{\theta} \mathrm{k}$

Subject to: $-Y_{i}+Y \lambda \geq 0$

$$
\begin{aligned}
& \theta \mathrm{X}_{\mathrm{i}}^{\mathrm{k}}-\mathrm{X}^{\mathrm{k}} \lambda \geq 0 \\
& \mathrm{X}_{\mathrm{i}}^{\mathrm{n}-\mathrm{k}}-\mathrm{X}^{\mathrm{n}-\mathrm{k} \lambda} \geq 0 \\
& \mathrm{~N} 1^{\prime} \lambda=1 \\
& \lambda \geq 0
\end{aligned}
$$

Where: ${ }^{\theta} \mathrm{k}$ is the input $\mathrm{k}$ sub vector technical efficiency scores form i. The constraints with terms $\mathrm{X}_{\mathrm{i}}^{\mathrm{k}}$ and $\mathrm{X}^{\mathrm{k}}$ includes only the $\mathrm{K}^{\text {th }}$ input in the third constraint, which contains $\mathrm{X}_{\mathrm{i}}^{\mathrm{n}-\mathrm{k}}$ and $\mathrm{X}^{\mathrm{n}-\mathrm{k}}$.

\subsubsection{Economic Efficiency}

Economic efficiency is a product of technical efficiency and allocative efficiency. Data Envelopment Analysis (DEA) computed economic efficiency by multiplying technical efficiency and allocative efficiency for each small holder sugarcane farmer at once. The model specification for economic efficiency is shown in the equation below:

$$
\mathrm{EE}=\mathrm{TE} \times \mathrm{AE}
$$

$\mathrm{EE}=$ Economic Efficiency

$\mathrm{TE}=$ Technical Efficiency

$\mathrm{AE}=$ Allocative Efficiency

\subsection{Impact of Farmer Characteristics and Goal Orientations on Production Efficiency}

Ordinary least square (OLS) linear regression model was used to establish the impact of farmers' socioeconomic characteristics and goal orientations on technical, allocative and economic efficiencies as shown below:

$$
\begin{array}{r}
\theta=\mathrm{b}_{0}+\mathrm{a}_{1} \mathrm{EDUC}+\mathrm{a}_{2} \mathrm{EXPE}+\mathrm{a}_{3} \mathrm{AGE}+\mathrm{a}_{4} \mathrm{HHSZE}+\mathrm{a}_{5} \text { GNDR }+\mathrm{a}_{6} \text { OCCUPTN }+\mathrm{a}_{7} \mathrm{GOAL}_{1} \\
+\mathrm{a}_{8} \mathrm{GOAL}_{2}+\mathrm{a}_{9} \mathrm{GOAL}_{3}+\mathrm{a}_{10} \mathrm{GOAL}_{4}+\mathrm{a}_{11} \mathrm{GOAL}_{5}+\mathrm{U}^{*} \ldots \ldots \ldots \ldots \ldots \ldots . . . \ldots \ldots
\end{array}
$$

Where:

$\mathrm{b}_{0}=$ Constant or intercept

$\mathrm{U}^{*}=$ error term

a1- $\mathrm{a}_{11}=$ Unknown scalar parameters to be estimated

EDUC = years in school of farmer

$\mathrm{EXPE}=$ farming experience in years 
$\mathrm{AGE}=$ age of farmer in years

HHSZE $=$ size of household in number

GNDR $=$ gender $($ female $=1$, male $=0)$

OCCUPTN $=$ occupation of the farmer $($ farmer $=1$, otherwise $=0$ )

$\mathrm{GOAL}_{1}=$ Instrumental orientation

$\mathrm{GOAL}_{2}=$ Sustainable orientation

$\mathrm{GOAL}_{3}=$ Family and leisure orientation

$\mathrm{GOAL}_{4}=$ Expressive orientation

$\mathrm{GOAL}_{5}=$ Social status orientation

$\theta=$ technical efficiency, allocative efficiency, economic efficiency

\subsection{Principal Component}

Farmers' goals were ordered and factors were subject to Varimax rotation performed by Principal Component Method. The Principal Component could take different forms of measurements and these included continuous variables, quantity of related products of values that make up a component and weighted values (generated values) from the component loading.

Principal component equation is written as follows:

$\mathrm{PC}_{1}=\alpha_{11} \mathrm{X}_{1}+\alpha_{12} \mathrm{X}_{2}+$ .$\alpha_{1 j} X_{j}$

Where: $\mathrm{PC}_{1}=$ first principal component. $\mathrm{X}_{1}$ and $\mathrm{X}_{2}$ are first and second independent variables of $\mathrm{PC}_{1}$. $\mathrm{a}_{11}$ and $\alpha_{12}$ are coefficients associated with $\mathrm{X}_{1}$ and $\mathrm{X}_{2}$ variables.

\subsection{Impact of Farmer Characteristics on Goal Orientations}

Ordinary least square (OLS) linear regression model was used to establish the impact of farmers' socioeconomic characteristics on goal orientations as shown below:

$$
\theta=\mathrm{s}_{0}+\mathrm{p}_{1} \mathrm{HHSZE}+\mathrm{p}_{2} \mathrm{GNDR}+\mathrm{p}_{3} \mathrm{AGE}+\mathrm{p}_{4} \mathrm{EDUC}+\mathrm{p}_{5} \mathrm{EXPE}+\mathrm{p}_{6} \mathrm{OCCPTN}+\mathrm{p}_{7}
$$

Off-FARM $+\mathrm{U}^{*}$

Where:

$\mathrm{s}_{0}=$ Constant or intercept

$\mathrm{U}^{*}=$ error term

$\mathrm{p}_{1}-\mathrm{p}_{7}=$ Unknown scalar parameters to be estimated

HHSZE $=$ Size of household of the respondent

GNDR $=$ Gender of respondent $(1=$ female, $0=$ male 
$\mathrm{AGE}=$ Age of respondent in years

$\mathrm{EDUC}=$ Level of education of the respondent

$\mathrm{EXPE}=$ Farming experience in years

OCCPTN $=$ Occupation of respondent $(1=$ farmer, $0=$ otherwise

OFF-FARM $=$ Number of years in off-farm employment

$\theta=$ Instrumental orientation $\left(\mathrm{GOAL}_{1}\right)$, Sustainable orientation $\left(\mathrm{GOAL}_{2}\right)$, Family and leisure orientation $\left(\mathrm{GOAL}_{3}\right)$, Expressive orientation $\left(\mathrm{GOAL}_{4}\right)$ or Social status orientation $\left(\mathrm{GOAL}_{5}\right)$

\section{Findings and Discussion}

\subsection{Socioeconomic Characteristics}

Table 3 reveals household heads were mainly "husband" (42.2\%), "wife" $(51.7 \%)$ and "child" $6.1 \%$. Fifty seven (57.1\%) percent of the respondents were females while forty three (42.9\%) percent were males. This implies that there were more females than males in sugarcane production. Men were engaged in off-farm work. There were $87.1 \%$ married, $9.5 \%$ widows and $3.4 \%$ single household heads. All of the respondents had formal education with the majority having attended secondary school (38.8\%), primary school (30.6\%) and high school $(23.8 \%)$ and a few tertiary levels $(6.8 \%)$. The study further revealed that the average age of respondents was 56 years, household size of about 10 people and 9 years in formal school. The age of a household head represents general decision making ability (Martz, 2006).

Table 3. Status and educational backgrounds of farmers $(n=147)$

\begin{tabular}{l|l|l|l}
\hline Farm/farmer characteristics & Description & Frequency & Percentage \\
\hline Position of household head & Husband & 62 & 42.2 \\
& Wife & 76 & 51.7 \\
& Child & 9 & 6.1 \\
\hline \multirow{2}{*}{ Gender } & Male & 63 & 42.9 \\
& Female & 84 & 57.1 \\
\hline Marital Status & Married & 128 & 87.1 \\
& Widow & 14 & 9.5 \\
& Single & 5 & 3.4 \\
\hline Level of education & Primary & 45 & 30.6 \\
& Secondary & 57 & 38.8 \\
& High school & 35 & 23.8 \\
& Tertiary & 10 & 6.8 \\
\hline
\end{tabular}

The results further established that farmers had 10 years of farming experience cultivating on 4.5 hectares as indicated in Table 4. The average farming experience indicated that most of the sugarcane growers had relatively sufficient experience in sugarcane production. Sihlongonyane (2014) argued that farming experience increases efficiency of a smallholder farmer while Tew (2010) noted that smallholder sugarcane farmers were likely to set realistic 
goals as a result of varsity experience.

Table 4. Farm and farmer characteristics $(n=147)$

\begin{tabular}{l|l|l}
\hline Farm/farmer characteristics & Mean & Standard Deviation \\
\hline Household size & 9.63 & 4.976 \\
Age & 56.47 & 9.394 \\
Years in school & 8.82 & 3.819 \\
Farming experience & 10.04 & 5.588 \\
Land size & 4.456 & 6.429 \\
\hline
\end{tabular}

The majority of the farmers $(87.1 \%)$ in Table 5 were allocated land by Chiefs and only $4.8 \%$ farmers having purchased the land on which they are growing sugarcane. Table 5 also indicated that only $8.2 \%$ farmers were using inherited land from their parents. This implies that the majority of the smallholder farmers were producing sugarcane on Swazi Nation land where there are no Title Deeds (Masuku et al., 2014).

Table 5. Land acquisition $(\mathrm{n}=147)$

\begin{tabular}{l|l|l|l}
\hline Access to land & Description & Frequency & Percentage \\
\hline Who set rules about land acquisition & Traditional Community & 120 & 81.6 \\
\hline $\begin{array}{l}\text { How you accessed land under } \\
\text { cultivation }\end{array}$ & Government & 27 & 18.4 \\
\hline & Purchased land & 7 & 87.1 \\
\hline
\end{tabular}

The study further revealed that eighty two (81.6\%) percent of the farmers indicated that rules regarding land access were set by traditional community and eighteen (18.4\%) percent reported that rules were set by the government. Table 6 reveals that $100 \%$ of the respondents had access to facilities like credit, extension services, accounting services, soil analysis and water testing services. 
Table 6. Facilities, irrigation and cultivars $(\mathrm{n}=147)$

\begin{tabular}{l|l|l|l}
\hline Facilities/irrigation & Description & Frequency & Percentage \\
\hline Access to facilities & Extension & 147 & 100 \\
& Credit \& Accounts & 147 & 100 \\
& Soil \& water testing & 147 & 100 \\
\hline Irrigation & Overhead & 127 & 86.4 \\
& Furrow & 20 & 13.6 \\
\hline \multirow{2}{*}{ Sugarcane cultivars } & N19 & 12 & 08.1 \\
& N23 & 63 & 42.9 \\
& N25 & 72 & 49.0 \\
\hline
\end{tabular}

In a study carried out by Dlamini and Dlamini (2012), it was revealed that seventy eight (77.5\%) percent of the smallholder sugarcane farmers had easy access to service facilities. The current results show that there was great stride in improving easy accessibility to service facilities by the government of Swaziland and private sector. Furthermore, sugarcane in the study area was grown using overhead $(86.4 \%)$ and furrow $(13.6 \%)$ irrigation systems. Regarding sugarcane varieties, forty nine (49\%) percent of the smallholder farmers indicated that they were growing $\mathrm{N} 25$. Very few respondents $(8.1 \%)$ reported that they were growing N19 with about forty three (42.9\%) growing N23. The study further revealed that smallholder farmers obtained an average sucrose yield of 90.69 tonnes per hectare per annum as indicated in Table 7. This is less than what SSA (2015) obtained, which was 101 tonnes per hectare per annum. The SSA (2015)'s findings were inclusive of large scale sugarcane estates which were more efficient.

Regarding labour, the study revealed an average of 33.05 man days per hectare per annum. In a study by Dlamini and Masuku (2012) labour was reported to be 31.25 days per hectare per annum among sugarcane farmers which is less than what was found in the study. On average a smallholder farmer used $15543.92 \mathrm{~m}^{3}$ of water to irrigate one hectare of sugarcane per annum. Fertilizer (basal \& urea) share in the production of sugarcane constitutes a mean of 654.10 kilogrammes $(\mathrm{kg})$ per hectare per annum. The study further revealed that on average a farmer used 12.07 litres of herbicides per hectare per annum. Dlamini and Masuku (2012) reported that smallholder farmers used 14.3 litres of chemicals (herbicides) per hectare per annum which is more than what was found in the study. On average, smallholder farmer used 1.27 litres ripeners per hectare per annum. 


\section{Macrothink}

Table 7. Farmers' inputs into sugarcane production $(\mathrm{n}=147)$

\begin{tabular}{l|l|l}
\hline Variable & Mean & Standard Deviation \\
\hline Quantity of sucrose (Tonnes/hectare) & 90.69 & 15.822 \\
\hline Labour in man days/hectare & 33.05 & 5.764 \\
\hline Quantity of water (m3/hectare) & 15543.92 & 1961.774 \\
\hline Quantity of fertilizer (kg/hectare) & 654.10 & 117.241 \\
\hline Quantity of herbicide (litres/hectare) & 12.07 & 2.603 \\
\hline Quantity of ripeners (litres/hectare) & 1.267 & 0.6567 \\
\hline
\end{tabular}

\subsection{Farmers' Goals}

The farmers' goals were solicited using the 4 point Likert scale where "1" was extremely not important and "4" was extremely important. The respondents were implored to rate the rank of 20 out of 22 attitudinal statements pertaining to smallholder sugarcane farmers' goals. The goals were then clustered into five orientations called principal components based on Gason (1973), Fairweather and Keating (1990), Padilla-Fernandez and Nuthall (2001), Kibirige (2013) and Kibirige et al. (2016). The five goal orientations generated include Instrumental orientation (GOAL 1), Sustainable orientation (GOAL 2), Family and leisure orientation (GOAL 3), Expressive orientation (GOAL 4) and Social status orientation (GOAL 5) as indicated in Table 8.

The instrumental orientation in Table 8 was considered most important with a total mean value of 3.73. The goal that scored highly in this component was "increase standard of living" (mean $=3.82, \mathrm{SD}=0.422$ ). The other goals were "it is important to maximise profit" $($ mean $=3.74, \mathrm{SD}=0.484)$, "increase maximum farm income" (mean $=3.72, \mathrm{SD}=0.465)$, "keep debts as low as possible" (mean $=3.7, \mathrm{SD}=0.59$ ) and "expand farm business" (mean $=3.66, \mathrm{SD}=0.543)$. These respondents were concerned about sugarcane farming as a business with maximisation of utilities. 
Table 8. Analysis of farmers' goals $(n=147)$

\begin{tabular}{|c|c|c|}
\hline Farmers' goals & Mean & Standard Deviation \\
\hline \multicolumn{3}{|l|}{ Instrumental Orientation (GOAL 1) } \\
\hline It is important to make maximum profit & 3.74 & 0.484 \\
\hline Expand farm business & 3.66 & 0.543 \\
\hline Increase maximum farm income & 3.72 & 0.465 \\
\hline Keep debts as low as possible & 3.70 & 0.590 \\
\hline Increase standard of living & 3.82 & 0.422 \\
\hline Average & 3.73 & 0.501 \\
\hline \multicolumn{3}{|l|}{ Sustainable Orientation ( GOAL 2) } \\
\hline It is because parents were farmers & 2.55 & 1.304 \\
\hline Provide employment to rural people & 2.87 & 0.931 \\
\hline Leave business for next generation & 3.11 & 1.014 \\
\hline Being able to arrange hours of work & 3.24 & 0.791 \\
\hline Doing work you like & 3.23 & 0.713 \\
\hline Average & 3.00 & 0.951 \\
\hline \multicolumn{3}{|l|}{ Family \& Leisure Orientation (GOAL 3) } \\
\hline Avail time to spend with family & 3.23 & 0.703 \\
\hline Have more leisure time & 3.58 & 0.618 \\
\hline Involve family in decision making & 3.37 & 0.653 \\
\hline Self-employment and independence & 3.60 & 0.659 \\
\hline Average & 3.45 & 0.658 \\
\hline \multicolumn{3}{|l|}{ Expressive Orientation (GOAL 4) } \\
\hline Recognised as a top producer & 3.60 & 0.637 \\
\hline Recognised as owner of land & 3.63 & 0.653 \\
\hline Recognised as a technology adopter & 3.28 & 0.757 \\
\hline Recognised as sugarcane farmer & 3.40 & 0.791 \\
\hline Average & 3.48 & 0.710 \\
\hline \multicolumn{3}{|l|}{ Social Status Orientation (GOAL 5) } \\
\hline To be in contact with people $\&$ share information & 3.61 & 0.726 \\
\hline Belong to farming community & 3.12 & 0.784 \\
\hline Average & 3.37 & 0.755 \\
\hline
\end{tabular}

The expressive orientation component involved respondents who were aspiring for recognition, prestige and excellence. It is composed of four goals with an average mean value of 3.48. The goals were as follows: "recognised as top producer" (mean $=3.6, \mathrm{SD}=0.637$ ), "recognised as owner of land" (mean $=3.63$, SD =0.653), "recognised as technology adopter" (mean $=3.28, \mathrm{SD}=0.757)$ and "recognised as sugarcane farmer" (mean $=3.4, \mathrm{SD}=$ 0.791). The respondents were concerned about their own welfare and survival and future financial situation of the sugarcane business. Based on the analysis results, family and leisure orientation comprises of four goals with a total mean value of 3.45. The component had respondents that were concerned about leisure, family and independence. The goals in this 
category were as follows: "avail time to spend with family" (mean $=3.23, \mathrm{SD}=0.703$ ), "have more leisure time" ( $m e a n=3.58, \mathrm{SD}=0.618)$, "involve family in decision making" (mean $=3.37, \mathrm{SD}=0.653$ ) and "self-employment and independence" (mean $=3.6, \mathrm{SD}=$ 0.659). In the social status orientation category, the respondents were concerned with welfare of other farmers and sharing of information with them. The social status orientation consists of two goals with a total mean value of 3.37. The goals were "to be in contact with people and share information" (mean $=3.61, \mathrm{SD}=0.726$ ) and "belong to farming community" (mean $=3.12, \mathrm{SD}=0.784)$.

The sustainable orientation principal component had the least total mean value of 3.00. The goal that scored lowly was "it is because parents were farmers" ( The other goals were "provide employment to rural people" (mean $=2.87, \mathrm{SD}=0.931$ ), "leave business for the next generation" (mean $=3.11, \mathrm{SD}=1.014)$, "being able to arrange hours of work" (mean $=3.24, \mathrm{SD}=0.791)$ and "doing work you like" (mean $=3.23, \mathrm{SD}=$ 0.713). Therefore, the smallholder sugarcane farmers farm in order to satisfy their instrumental (business), expressive (prestige \& excellence), family and leisure (self-esteem \& independence), social status (information sharing \& sense of belonging) and sustainable (welfare of future generation) related demands. This implies that smallholder farmers had confidence and interest in farming resulting in high productivity levels of individuals. This is anticipated to improve livelihood and reduce hunger and poverty among the rural sugarcane farming communities.

\subsubsection{Principal Components of Farmers' Goals}

Factor analysis was used to approximate the principal components of the farmers' goals. In this study 20 goal statements were condensed into fewer explained goal orientations. During the analysis, all goal statements were taken into consideration and were congruent with the minimum Kaiser-Meyer-Olkin (KMO) measure of sampling adequacy value of 0.60 . The KMO of the current study was 0.813 and passed the Bartlett's Test of Sphericity with no autocorrelation among variables. Furthermore, the Eigen value proportions of variance for the selecting optimal number of principal components were above the recommended value of 1 . The entire twenty goals related statements passed the mandatory tests and were considered in the factor loading statistical measurement process. The goal statements generated five principal components with $60 \%$ of variation in the explanatory variables. Kibirige (2013) and Padilla-Fernandez and Nuthall (2001) inscribed that any estimated coefficiency score greater than 0.3 of a goal is considered significant for that goal to belong to a principal component. The five principal components generated were instrumental orientation (PC1), sustainable orientation (PC2), family and leisure orientation (PC3), expressive orientation (PC4), and social status orientation (PC5).

The first principal component (instrumental orientation) in Table 9 exhibits a variation of $29.12 \%$ in farmers' rating of their goals. The principal component was best described as instrumental, business or developmental oriented goals. There were five farmers' related goals that had estimated coefficients above 0.30 and defined this principal component. The farmers were interested in creating maximum profit and income, increasing standard of living, 
expanding farm business and reducing debts. The business ego goals may be of great necessity to farmers for better performance as they strive to accomplish these ambitions. In support Kibirige et al. (2016) noted that farmers' business goals can therefore be incorporated in rural development programmes for improved smallholder farmers' incomes and general livelihood. The second principal component accounted for 9.87\% variations in the explanatory variables and mainly comprises of the sustainability aspiration. This principal component includes five goals which were parents were farmers, providing employment to rural people, leaving business for next generation, being able to arrange hours of work and doing work you like. Although most smallholder sugarcane farmers did not inherit their business they aspire to pass on their enterprises to the next generation. They desire the farm business to continue into the future and augment livelihood of their children and the community. They also aspired to do work they like and freely schedule their work. Therefore for continuity purposes, programmes that encourage participation of farmers' children (especially young people) should be established.

The third principal component generated revealed $7.8 \%$ of variations in the explanatory variables and mainly composed of independence, family and leisure goals. This principal component included four aspirations which were availing time to spend with family, having more leisure time, self-employment and independence and involving family in decision making. Farmers viewed farming as source of family congregation, personal freedom, independence and leisure time. Family gatherings provide opportunities for sharing farming experiences and new ideas by older and educated members respectively. Moreover, more leisure time, self-employment and independence enhance farmers to participate in social gatherings. Kibirige (2013) noted that the majority of rural population in developing countries engages in smallholder farming as major source of livelihood and self-employment. This attribute can be enhanced by promoting smallholder farming as business and source of self-employment among rural sugarcane communities.

The fourth principal component factored in, can be best defined as farmers' expressive, feeling or prestigious goals and was explained by $7.1 \%$ of variations in the explanatory variables. The principal component comprised of goals like recognised as top producers, recognised as owner of land, recognised as technology adopter and recognised as sugarcane farmer. The farmers desired excellence among peers to own land and perceived as being prestigious and powerful to belong to sugarcane farming community (Padilla-Fernandez \& Nuthall, 2001; Basarir, 2002; Pereira, 2011). Therefore, programmes that reward and appreciate individual efforts should be put in place. The last principal component generated revealed $6.07 \%$ of variations in the explanatory variables and was explained as farmers' social status and sense of belonging. 
Table 9. Principal components of farmers' goals $(n=147)$

\begin{tabular}{|c|c|c|c|c|c|}
\hline & Instrumental & Sustainable & $\begin{array}{l}\text { Family } \\
\& \\
\text { Leisure }\end{array}$ & Expressive & $\begin{array}{l}\text { Social } \\
\text { status }\end{array}$ \\
\hline Proportion of variance (\%) & 29.120 & 9.872 & 7.798 & 7.102 & 6.072 \\
\hline \multirow[t]{2}{*}{ Eigen values } & 5.824 & 1.974 & 1.560 & 1.420 & 1.214 \\
\hline & \multicolumn{5}{|c|}{ Factor Loadings } \\
\hline Farmers' goals & PC 1 & PC 2 & PC 3 & PC 4 & PC 5 \\
\hline $\begin{array}{l}\text { It is important to make maximum } \\
\text { profit }\end{array}$ & $\underline{0.858}$ & 0.105 & & & 0.160 \\
\hline Expand farm business & $\underline{0.820}$ & 0.149 & 0.164 & & \\
\hline Increase maximum farm income & 0.767 & 0.223 & 0.136 & & \\
\hline Keep debts as low as possible & $\underline{0.725}$ & & 0.101 & & 0.245 \\
\hline Increase standard of living & $\underline{0.583}$ & 0.189 & 0.287 & 0.163 & -0.127 \\
\hline It is because parents were farmers & & 0.837 & & -0.157 & \\
\hline $\begin{array}{l}\begin{array}{l}\text { Provide employment to rural } \\
\text { people }\end{array} \\
\end{array}$ & & $\underline{0.673}$ & 0.215 & & 0.405 \\
\hline Leave business for next generation & 0.181 & $\underline{0.652}$ & 0.166 & 0.227 & $\underline{0.366}$ \\
\hline $\begin{array}{l}\text { Being able to arrange hours of } \\
\text { work }\end{array}$ & 0.233 & $\underline{0.619}$ & $\underline{0.303}$ & & \\
\hline Doing work you like & 0.254 & $\underline{0.533}$ & & & \\
\hline Avail time to spend with family & 0.125 & 0.250 & 0.829 & & \\
\hline Have more leisure time & & -0.112 & $\underline{0.679}$ & 0.116 & $\underline{0.371}$ \\
\hline Involve family in decision making & 0.296 & 0.195 & $\underline{0.63}$ & & -0.149 \\
\hline Self-employment \& independence & $\underline{0.344}$ & 0.153 & $\underline{0.473}$ & 0.193 & \\
\hline Recognised as a top producer & & & & $\underline{0.721}$ & \\
\hline Recognised as owner of land & & -0.146 & & $\underline{0.684}$ & \\
\hline $\begin{array}{l}\begin{array}{l}\text { Recognised as a technology } \\
\text { adopter }\end{array} \\
\text { ldopt }\end{array}$ & 0.243 & $\underline{0.390}$ & 0.179 & $\underline{0.592}$ & \\
\hline Recognised as sugarcane farmer & 0.284 & $\underline{0.302}$ & 0.150 & $\underline{0.474}$ & 0.228 \\
\hline $\begin{array}{l}\text { To be in contact with people \& } \\
\text { share info }\end{array}$ & & & & & $\underline{0.776}$ \\
\hline Belong to farming community & $\underline{0.351}$ & $\underline{0.372}$ & 0.145 & & $\underline{0.655}$ \\
\hline $\begin{array}{l}\text { Kaiser-Meyer-Olkin (KMO) Measur } \\
\text { Bartlett's Test of Sphericity: Approx. } \\
\text { Degree of Freedom }=190 \\
\text { Level of Significance }=1 \%\end{array}$ & $\begin{array}{l}\text { of Sampling } \\
\text { Chi-Square }=1(\end{array}$ & $\begin{array}{l}\text { dequacy }=0.8 \\
48.573\end{array}$ & & & \\
\hline
\end{tabular}

The fifth principal component comprised of goals like belonging to farming community and being in contact with people and share information. Community gathering provides opportunity for smallholder sugarcane farmers to share information about farming. 
Furthermore, sugarcane farmers desire to get along with their peers (Pereira, 2011).

\subsubsection{Farmers' Goals and Socio-economic Characteristics}

In order to determine relationships between farmers' goals and farmers' socioeconomic characteristics a multiple regression analysis model was used. Analysis of results in Table 10 has established a significant relationship between the farmer characteristics and farmer's goals. The regression model related to farmers' goals of instrumental orientation (GOAL 1), sustainable orientation (GOAL 2), family and leisure orientation (GOAL 3), expressive orientation (GOAL 4) and social status (GOAL 5) were significant at $1 \%$ level respectively. There was low extent of autocorrelation registered within the regression model since results exhibited a Durbin-Watson statistics greater than 1 (Kibirige et al., 2016; Kibirige, 2013; Padilla-Fernandez \& Nuthall, 2001).

The study results in Table 10 reveal that instrumental orientation (business) was positively and significantly related to gender at $1 \%$ significant level. This implies that female farmers are more oriented to business goals than males do. The results are not in line with Basarir (2002)'s findings which revealed that males were more business oriented than females in beef production. Age and education were positively and significantly related to instrumental (business) orientation at $1 \%$ and $10 \%$ significant levels, respectively. This implies that a year increase in age and educational level of the farmer, improves the instrumental (business) goal. This means old and educated farmers view farming as a business. This is in conformity with Pereira (2011)'s findings where age and educational levels positively influenced business oriented goals. Farming as major occupation is positively and significantly related to instrumental orientation at 5\% level. This implies that those engaged in farming, as a major occupation, were for increased output. This results in increased income, high standard of living and accumulated wealth (Kibirige et al., 2016).

Off-farm work is positively related to instrumental (business) orientation at 5\% significant level. This implies that off-farm income complements the farm business. The study results are in line with Pereira (2011)'s findings where off-farm work was positively related to instrumental (business) orientation. This means that off-farm work is for financing farming business. Surprisingly, farming experience is negatively related to instrumental orientation at $1 \%$ significant level. This is contrary to Padilla-Fernandez and Nuthall (2001)'s findings where farming experience was positively related to instrumental orientation. This means experienced farmers no longer view farming as means of obtaining income and security but rather an enjoyable part of lifestyle (Fairweather \& Keating, 1990). Basing on the study results, gender is positively and significantly related to sustainable orientation at $5 \%$ significant level. This implies that female sugarcane farmers perceive sustainable orientation important more than male sugarcane farmers do. Female sugarcane farmers would likely improve sustainable orientation goals. Furthermore, age is positively and significantly associated with sustainable orientation at $10 \%$ significant level. This implies that an increase in age of a farmer will improve sustainable orientation. Older farmers may likely want to pass farming operations to future generation. The old farmers put more attention on preserving land for future generation and view farming business as a secure retirement option 
(Padilla-Fernandez \& Nuthall, 2001; Basarir, 2002; Pereira, 2011).

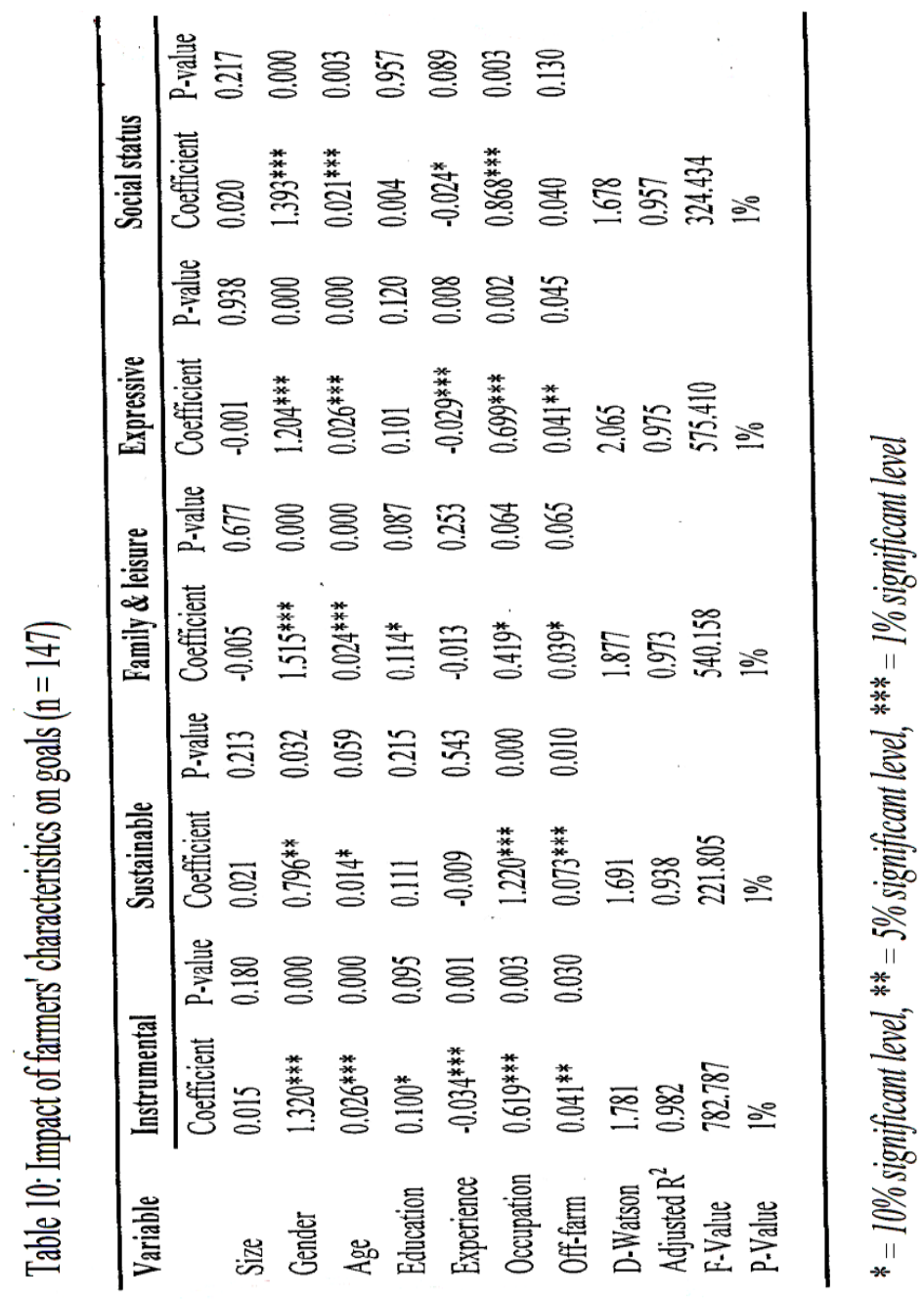

Farming as a major occupation has a positive and significant impact on farmers' sustainable goals at $1 \%$ significant level. This implies that smallholder producers whose major occupation is farming consider sustainable orientation goals important. This is an indication that considering farming as a major occupation improves farmers' confidence to do work that he/she like to do, improve the farm for future generation and spend more time on farming activities (Kibirige, 2013). Off-farm work had a positive and significant relationship with sustainable orientation at $1 \%$ significant level. This implies that an increase in one year of off-farm work will improve sustainable orientation. Income from off-farm work will be used to improve the farm for secured retirement option and preserve the farm for future generation (Padilla-Fernandez \& Nuthall, 2001; Basarir, 2002).

Family and leisure orientation is positively and significantly associated with gender, age (1\% significant level), respectively, occupation, off-farm work and education (10\% significant level), respectively. This implies that female sugarcane farmers view family and leisure (independence) orientation more important than males do. A year increase in age and education level of a farmer will improve family and leisure orientation. The results of the study are in line with Kibirige et al. (2016)'s findings which revealed that age and education 
were positively related to independence and leisure goals. Furthermore, an increase in years of farming as a major occupation will improve family and leisure orientation. This implies that farmers perceive farming as having more freedom, independence and leisure time (Padilla-Fernandez \& Nuthall, 2001; Martz 2006). Moreover, an increase in years in off-farm work will improve family and leisure orientation. The family and leisure activities are likely to be financed by off-farm income. The results of the study did not conform to Basarir (2002)'s findings where off-farm work was negatively related to family and leisure orientation goals.

Determinants of expressive orientation include gender, age, farming experience, occupation and off-farm work. Gender and age had a positive and significant impact on expressive orientation at $1 \%$ significant levels. This implies that female sugarcane farmers perceive expressive orientation more important than males do. A year increase in age of a farmer will improve expressive orientation. Farming experience had a negative and significant influence on expressive orientation at $1 \%$ significant level. This implies that less experienced farmers tend to perceive that farming is more prestigious. Sugarcane farming as a major occupation is positively related to expressive orientation at $1 \%$ significant level. This implies that sugarcane farmers perceive farming as a prestigious operation.

Furthermore, off-farm work had positive and significant impact on expressive orientation at 5\% significant level. The results of the study are consistent with Kibirige (2013)'s findings which revealed that off-farm income was positively and significantly related to expressive orientation. Factors positively and significantly related to social status orientation include gender, age and occupation of the farmer at $1 \%$ significant levels and negatively related to farming experience at $10 \%$ significant level. This implies that female farmers perceive social status orientation to be more important than male farmers do. An increase in the age of the farmer will improve social status orientation. The results of the study conform to Kibirige (2013)'s findings which revealed that age had positive and significant impact on social status. Farmers are interested in spending their leisure time with other farmers sharing information (Basarir, 2002). Therefore policies should be designed among smallholder sugarcane farmers that boost farmers' goal orientations so as to enhance productivity.

\subsection{Production Efficiency}

In this study Technical Efficiency (TE), Allocative Efficiency (AE) and Economic Efficiency (EE) were generated using DEAP version 2.1. Data were analysed using DEA Frontier Analysis (input oriented and Cost-DEA) with constant return to scale (CRS) model. The results in Table 11 reveal a mean technical efficiency of $89.57 \%$ with minimum and maximum of $51.7 \%$ and $100 \%$, respectively. This suggests that there exists a great potential for smallholder farmers to increase yield per hectare of sugarcane. If on average the smallholder sugarcane farmers are to operate efficiently, they would achieve an input saving of $10.43 \%$ or maximise yield by the same. 
Table 11. The estimator of efficiencies

\begin{tabular}{l|l|l|l|l}
\hline Efficiency & $\begin{array}{l}\text { Minimum } \\
(\%)\end{array}$ & Maximum (\%) & Mean (\%) & Standard Deviation \\
\hline Technical & $51.7 \%$ & $100 \%$ & $89.57 \%$ & 0.127359 \\
\hline Allocative & $50.5 \%$ & $100 \%$ & $84.94 \%$ & 0.111524 \\
\hline Economic & $38.5 \%$ & $100 \%$ & $76.43 \%$ & 0.162424 \\
\hline
\end{tabular}

The mean allocative efficiency was revealed to be $84.94 \%$ with minimum and maximum of $50.5 \%$ and $100 \%$, respectively. This indicates that there exists a potential for smallholder farmers to increase yield per hectare of sugarcane. If on average the smallholder sugarcane farmers are to operate efficiently, they would achieve a cost saving of $15.06 \%$, while maintaining same output. The study further revealed a mean economic efficiency of $76.43 \%$ with minimum and maximum of $38.5 \%$ and $100 \%$, respectively. This proposes that there exists a great potential for smallholder farmers to increase yield per hectare of sugarcane. Smallholder sugarcane farmers can reduce inputs costs by $23.57 \%$, while maintaining same out, or they can increase output by $23.57 \%$, while still maintaining same inputs and technology.

Table 12. Distribution of efficiencies $(\mathrm{n}=147)$

\begin{tabular}{|c|c|c|c|c|c|c|}
\hline \multirow[t]{2}{*}{ Efficiency range } & \multicolumn{2}{|c|}{ Technical Efficiency } & \multicolumn{2}{|c|}{ Allocative Efficiency } & \multicolumn{2}{|c|}{ Economic Efficiency } \\
\hline & Frequency & $\%$ & Frequency & $\%$ & Frequency & $\%$ \\
\hline $90-100$ & 92 & 62.59 & 57 & 38.78 & 35 & 23.81 \\
\hline $80-89.99$ & 25 & 17.01 & 47 & 31.97 & 39 & 26.53 \\
\hline $70-79.99$ & 15 & 10.2 & 24 & 16.33 & 23 & 15.65 \\
\hline $60-69.99$ & 7 & 4.76 & 16 & 10.88 & 26 & 17.69 \\
\hline 50-59.99 & 8 & 5.44 & 3 & 2.04 & 10 & 6.8 \\
\hline $40-49.99$ & 0 & 0 & 0 & 0 & 13 & 8.84 \\
\hline $30-39.99$ & 0 & 0 & 0 & 0 & 1 & 0.68 \\
\hline Total & 147 & 100 & 147 & 100 & 147 & 100 \\
\hline Average & 89.57 & & 84.94 & & 76.43 & \\
\hline Maximum & 100 & & & 100 & 100 & \\
\hline Minimum & 51.7 & & 50.5 & & 38.5 & \\
\hline
\end{tabular}


The results in Table 12 reveal that most farmers $(62.59 \%)$ achieved a technical efficiency between 90 and $100 \%$ and none got less than 50\%. Regarding allocative efficiency none of the farmers obtained less than $50 \%$ but thirty nine $(38.78 \%)$ percent of the respondents, attained allocative efficiency which was between 90 and $100 \%$. One $(0.68 \%)$ percent of the farmers got economic efficiency which is less than $40 \%$ with twenty four (23.81\%) percent achieving economic efficiency between 90 and 100\%. Considering the difference between maximum and minimum of the efficiencies accomplished, there is a lot of improvement that farmers need to do in order to operate at the frontier.

\subsubsection{Factors Affecting Production Efficiency}

In this study an ordinary least square (OLS) linear regression of technical, allocative and economic efficiency scores against explanatory variables were estimated. The inefficient effects were specified as those related to farmers' socioeconomic characteristics and the perceived farmers' goals. The OLS regression model representing technical, allocative and economic efficiency where Durbin-Watson value scores were 1.585, 1.429 and 1.207, respectively, signifying limited autocorrelation problems. The F-values exhibited that the explanatory variables combined, significantly influence changes in the dependent variables at $1 \%$ significant levels.

Analysis of results in Table 13 revealed that technical efficiency is positively and significantly related to age and level of education of the farmer at $1 \%$ significant levels. This implies that an increase in the age and educational level of a farmer will improve technical efficiency. The age of smallholder farmer plays a vital role in the rejection or selection of new practices and modern technology. Age represents general decision making ability and knowledge of production process. Farmer's age is accepted to have great contribution towards personal learning, personality development, attitude and skills with correct judgment (Supaporn, 2015; Muhammad, 2015; Kibirige et al., 2014; Aung, 2012; Ayaz \& Hussain, 2011). Thabethe et al. (2014) argued that older farmers appear to be more efficient than younger farmers because of their good managerial skills, which they had learnt over time.

It is conceivable that the level of education of a farmer will enhance production and lead to more efficient productivity as predicted in the empirical hypothesis. Education plays a great role in adoption of most new technologies that normally calls for better management including consistent record keeping and proper use of the various inputs in sugarcane (Kibirige, 2008). The results of the current study conforms to Muhammad (2015), Supaporn (2015), Kibirige et al. (2014), Thabethe et al. (2014), Ali et al. (2013) and Kibirige (2013)'s findings where educational level of a farmer was positively related to technical efficiency. However, Padilla-Fernandez and Nuthall (2001) found educational level of a farmer to be a weak predictor of technical efficiency while Kibirige et al. (2016) found educational level of a farmer to be negatively related to technical efficiency. The results further revealed that technical efficient is positively related to instrumental orientation (GOAL 1) at 5\% significant level. This implies that smallholder sugarcane farmers who perceive instrumental (business) goals important were likely to be more efficient than those who do not consider them important. Thus farmers' business expressions towards the progress of their sugarcane farms 
improve technical efficiency. The study results are not in line with Padilla-Fernandez and Nuthall (2001), Kibirige (2013) and Kibirige et al. (2016)'s findings which revealed that business oriented goals were negatively related to technical efficiency.

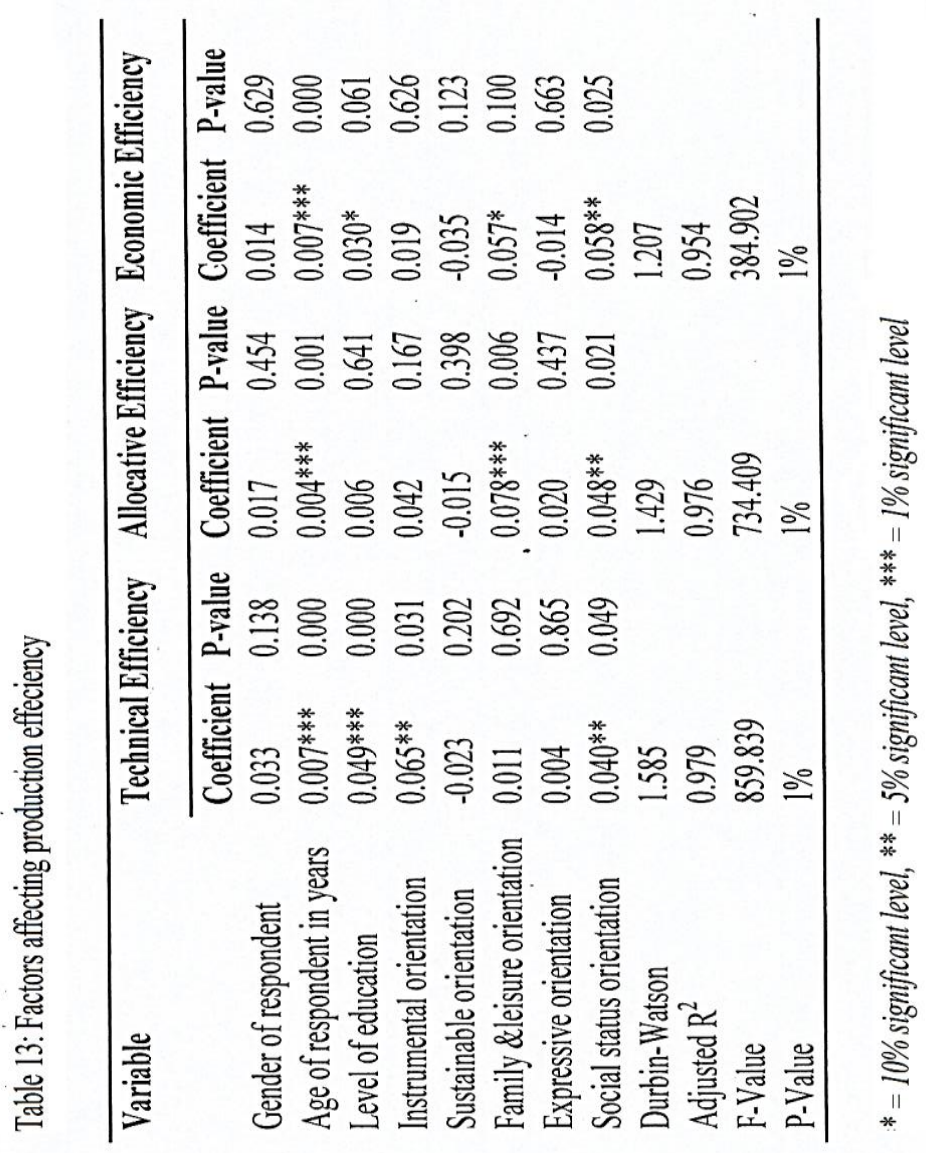

Further, social status orientation has positive and significant impact on technical efficiency at $5 \%$ significant level. Thus, farmers express their positive interest in sugarcane farming by means of a social gathering and belonging activity. Farmers who aspire to share information about managerial skills and use of modern technology were likely to be more technically efficiency than those who do not ascribe to that. The results of this study are inconsistent with Padilla-Fernandez and Nuthall (2001)'s findings which revealed that social status had a negative impact on technical efficiency. Based on analysis of results in Table 13, age has positive impact on allocative efficiency at $1 \%$ significant level. This implies that allocative efficiency will increase if there is a year increase in farmers' age. According to Ali et al. (2013) age is the main factor and it plays a vital role in rejection or selection of new practices and technology and use of scarce resources efficiently. The study further revealed a positive and significant relationship between family and leisure orientation (GOAL 3) and allocative efficiency at $1 \%$ significant level. This implies that farmers who perceive family and leisure (self-esteem, leisure \& independence) goals important were likely to be allocatively efficient than those who do not consider such goals as important. Thus, farmers were likely to give higher importance to having more leisure time and wanting to live a healthy, out-door, 
farming life (Padilla-Fernandez \& Nuthall, 2001). Producers are realizing greater utility of being a farmer and strive to allocate scarce resources efficiently so as to produce high quality product and develop the farm ((Basarir, 2002; Fairweather \& Keating, 1990).

The study further revealed that social status orientation has positive and significant impact on allocative efficiency at 5\% significant level. Thus, farmers in the study areas aspired positively to be in sugarcane farming by being interested in social gathering and belonging activities. Farmers who perceive sharing information about resource usage were likely to be more allocatively efficiency than those who do not ascribe to that. These farmers dedicate and allocate most of their time to social activities (Padilla-Fernandez \& Nuthall, 2001). The study furthermore revealed positive relationship between age of the farmer and economic efficiency at $1 \%$ significant level. This implies that a year increase in age of a farmer will increase economic efficiency. This is in line with empirical hypothesis. Furthermore, education level in terms of years spent in formal schools by the farmers had a positive and significant effect on economic efficiency at $10 \%$ significant level. This implies that a year increase in educational level of a farmer will increase economic efficiency. Education enhances farmers' ability to make optional decisions with regard to input use and product mix (Thabethe et al., 2014). In support, Kalinga (2014) documented that an increase in level of education contributes to an increase in economic efficiency. The results are in conformity with Thabethe et al. (2014)'s findings where education level is positively related to economic efficiency.

The study results revealed that family and leisure orientation (GOAL 3) has positive impact on economic efficiency at $10 \%$ significant level. Thus, farmers who perceive family and leisure (self-esteem, leisure \& independence) goals important were likely to be economically efficient than those who do not consider such goals as important. Economic efficient farmers tend to give higher importance to freedom and independence than the inefficient ones. Freedom in this sense signifies the ability to set one's work place and be free of close supervision (Padilla-Fernandez \& Nuthall, 2001). However, Padilla-Fernandez and Nuthall (2001)'s findings revealed a negative relationship which means there is no consistence with the current study. Furthermore, social status orientation (GOAL 5) has positive and significant impact on economic efficiency at $5 \%$ level. Thus, farmers who perceive sharing information about resource usage were likely to be more economically efficient than those who do not ascribe to that. That is, economic efficient farmers are more likely to give high importance to social identification, belonging and gathering (Padilla-Fernandez \& Nuthall, 2001).

\section{Conclusions and Recommendations}

\subsection{Conclusions}

The study concludes that smallholder farmers are engaged in sugarcane farming to achieve the goals. The findings of the study further revealed the average technical efficiency, allocative efficiency and economic efficiency of $89.57 \%, 84.94 \%$ and $76.43 \%$, respectively. Thus, there is a potential of increasing technical efficiency, allocative efficiency and economic efficiency by $10.43 \%, 15.06 \%$ and $23.57 \%$, respectively. Technically efficient farmers in the study focused on instrumental (business) and social status orientation (sense of belonging \& sharing of information) goals. The other determinants of technical efficient were 
age and education. Allocatively efficient farmers exhibited family and leisure orientation (self-esteem \& independence) and social status (sense of belonging\& sharing of information) goals. The other factor influencing allocative efficient was age. Determinants of economic efficiency were education and age. Economic efficient farmers tend to focus on family and leisure orientation (self-esteem \& independence) and social status (sense of belonging \& sharing of information) goals.

Basing on the findings of the study, the null hypothesis $\left(\mathrm{H}_{1}=\right.$ smallholder sugarcane farmers are technically, allocatively and economically not efficient in resource usage) was accepted and alternative hypothesis $\left(\mathrm{H} 1_{1}=\right.$ smallholder sugarcane farmers are technically, allocatively and economically efficient in resource usage) was rejected. Instrumental orientation (GOAL 1), family and leisure orientation (GOAL 3), social status orientation (GOAL 5), age and education are factors influencing technical efficiency, allocative efficiency and economic efficiency. Therefore, the null hypothesis $\left(\mathrm{HO}_{2}=\right.$ smallholder sugarcane farmers' socioeconomic characteristics do not influence technical, allocative and economic efficiency) was rejected and alternative hypothesis $\left(\mathrm{H}_{2}=\right.$ At least one of the smallholder sugarcane farmers' socioeconomic characteristics significantly influence technical, allocative and economic efficiency) was accepted.

\subsection{Recommendations}

\subsubsection{Recommendation for Policy}

The findings of this study indicated that most farmers were aged and lack vitality, entrepreneurship, enthusiasm, flexibility and excellence required for efficient farming. Recommendation is made for rural development programs and policies that target young farmers' engagement and education should be catalysed through provision of more land for sugarcane production and equitable distribution of land regardless of age. Therefore the available land should be exploitable by young farmers and provision of agronomic training in order to induce the desired agricultural transformation and development. Prudence should be considered that improved access to land and training as only entities may not automatically result into increased efficient productivity but rather farmers need to be supported financially for acquisition of capital and build their aptitudes in farm management and goal orientations.

In view of the fact that the farmers' goals as defined in this study are not things that are acquiescent to direct policy infringement, they can be indirectly fiddled with, through policy actions that affect their determinants. Therefore recommendation is made for a rationale collaborative policy actions over the medium to long term in response to the ways smallholder farmers perceive realities which are governed by socioeconomic characteristics such as gender of household head, age, education level, farming as an occupation, off-farm income and farming experience.

\subsubsection{Recommendation for Actions}

Due to increase in demand for quality sugar on hostile global markets, it is recommended that farmers use available resources efficiently to maximise output of high quality and increase use of latest high yielding sugarcane varieties so as to boost efficiency. It is further 
recommended that stakeholders in the agricultural sector should perceive instrumental (business), family and leisure and social status goal orientations important so as to enhance efficient productivity.

\subsubsection{Recommendation for Further Research}

For further study, it is recommended that there is need for research to compare goal orientations and efficiency of smallholder sugarcane farmers in KDD and LUSIP areas.

\section{Acknowledgement}

The authors are grateful to the late Prof. M. B. Masuku, Department of AEM, Faculty of Agriculture, University of Eswatini, Eswatini for his valuable suggestions and guidance. The authors are also thankful to the late Mr. E. Mutenheri, Ph.D. Scholar, Department of AEM, Institute of Postgraduate Studies, UNESWA, Eswatini, for his contribution. May their Souls Rest in Eternal Peace.

\section{References}

Ali, G., Ali-Shah, S. M., Jan, D., Jan, A., Fayaz, M., Ullah, I., \& Khan, M. Z. (2013). Technical Efficiency of Sugarcane Production in District Dera Ishamael Khan, Sarhad Journal of Agriculture, 29(4), 585-590.

Aung, N. M. (2012). Production Efficiency of Farmers and Millers in Myammar Rice Industry. Institute of Developing Economies, 47(1), 1-80.

Ayaz, S., \& Hussain, Z. (2011). Impact of Institutional Credit on Production Efficiency of Farming Sector: A Case Study of District Faisalabad. Pakistan Economic and Social Review, 49(2), 149-162.

Basarir, A. (2002). Multidimensional Goals of Farmers in the Beef Cattle and Dairy Industries. PhD Dissertation. Louisiana State University. Louisiana.

Crawford, J. (2014). Annual SADC Sugar Digest 2014: Your Guide to Sugar Industry. South African Sugar Journal, 1, 16-24.

Dindi, E. A. (2013). The Managerial Factors Influencing Sugarcane Production by Farmers of Mayoni Division, Mumias Sugar Company in Kenya. Masters' Thesis, Kenyatta University.

Dlamini, M. B., \& Masuku, M. B. (2012). Productivity of Smallholder Sugarcane Farmers in Swaziland: The Case of Komati Downstream Development Program (KDDP) Farmers' Associations. Environment and Natural Resources Research, 2(4), 1-7. https://doi.org/10.5539/enrr.v2n4p1

Dlamini, M. M., \& Dlamini, B. M. (2012). Explanatory Variables Associated with the Yield Performance Gap among Small-Medium-and Large-Scale Sugarcane (Saccharum officinarum) Growers at Ubombo Sugar, Big Bend, Swaziland. Asian Journal of Agricultural Sciences, 4(1), 32-39.

Dlamini, S., Masuku, M. B., \& Rugambisa, J. I. (2010). Technical Efficiency of the Small scale Sugarcane Farmers in Swaziland: A case study of Vuvulane and Big bend farmers. African Journal of Agricultural Research, 5(9), 935-940. 
Dlamini, S., Masuku, M. B., \& Rugambisa, J. I. (2012). Technical Efficiency of Maize Production in Swaziland: A stochastic Frontier Approach. African Journal of Agricultural Research, 7(42), 5628-5636. https://doi.org/10.5897/AJAR12.1204

Esterhuizen, D., \& Pickelsimer, C. (2014). Report on Supply and Demand Trends for Sugar in Swaziland. Global Agricultural Information Network; USDA Foreign Agricultural Services.

Fairweather, J. R., \& Keating, N. C. (1990). Management Styles O' Canterbury Farmers: A Study of Goals and Success from Farmers' Point of View. Agribusiness and Economics Research Unit, Lincoln University. Canterbury.

Food and Agriculture Organization (FAO) (2013). Swaziland BEFS Country Brief: Swaziland. Bio energy and Food Security Projects.

Gason, R. (1973). Goals and Values of Farmers. Journal of Agricultural Economics, 24(3), 521-542. https://doi.org/10.1111/j.1477-9552.1973.tb00952.x

Hlophe, L. C. (2014). Analysing the Impact of EU Trade Policy Reform on the Sustainability of Smallholders Sugarcane Farming in Swaziland. Masters' Thesis, University of the Free State. Bloemfontein.

Kalinga, A. (2014). Input Use Efficiency in the Madibira Smallholder Farmers' Irrigation Scheme in Tanzania. Masters' Thesis, Sokoine University of Agriculture. Morogoro.

Kibirige, D. (2008). Analysis of the Impact of the Agricultural Productivity Enhancement Program on the Technical and Allocative Efficiency of Maize Farmers in Masindi District. Masters' Thesis, Makerere University. Kampala.

Kibirige, D. (2013). The Impact Dimensions on Smallholder Farming in the Eastern Cape Province of South Africa. PhD Thesis, University of Fort Hare. Alice

Kibirige, D., Obi, A., Masuku, M. B., \& Singh, A. S. (2016). Farmers' Goals and Efficiency in Small-Scale Maize Production: The Case of Eastern Cape Province of South Africa. Agriculture, Forestry and Fisheries, 5(5), 191-201. https://doi.org/10.11648/j.aff.20160505.18

Kibirige, D., Raufu, M. O., \& Masuku, M. B. (2014). Efficiency Analysis of the Sub-Saharan African small-scale Agriculture: A Review of Literature on Technical Efficiency of Maize Production. Journal of Agriculture and Veterinary Science, 7(12), 124-131. https://doi.org/10.9790/2380-07122124131

Liversage, H., \& Jonckheere, S. (2014). Securing Livelihoods, Land and Natural Resource Rights through Inclusive Business Models: Lessons from Swaziland and Sao Tomé \& Principe. Annual World Bank Conference on Land and Poverty 2014; The World Bank Washington DC

Martz, D. J. F. (2006). Canadian Farm Women and Their Families Restructuring, Work and Decision Making. PhD Dissertation, University of Saskatchewan. Saskatoon.

Masuku, B. B., Masuku, M. B., \& Belete, A. (2014). Economic Efficiency of Smallholder Dairy Farmers in Swaziland: An Application of the Profit Function. Journal of Agricultural Studies, 2(2), 132-146. https://doi.org/10.5296/jas.v2i2.6046 


\section{Macrothink}

Journal of Agricultural Studies

ISSN 2166-0379

2021, Vol. 9, No. 3

Muhammad, S. (2015). Economic Analysis of Sugarcane Production and its Contribution to Farm Income of Farmers in Maigana Agricultural Zone of Kaduna State Nigeria. Masters' Thesis, Ahmadu Bello University, Zaria.

Padilla-Fernandez, M. D., \& Nuthall, P. (2001). Farmers' Goals and Efficiency in the Production of Sugarcane: The Philippine Case. Farm and Horticultural Management Research Report 07/2001, 2-37.

Parminter, T. G., \& Perkins, A. M. L. (2001). Applying An Understanding of Farmers' Values and Goals to their Farming Styles. Foundation of Research Science and Technology and Ag. Research, 59, 107-110. https://doi.org/10.33584/jnzg.1997.59.2273

Pereira, M. A. (2011). Understanding Technology Adoption and Non-Adoption: A Case Study of Innovative Beef Farmers from Mato Grosso do Sul State. PhD Thesis, Lincoln University. Canterbury.

Sihlongonyane, M. B. (2014). Economic Efficiency of Maize Production in Swaziland: A Case of Hhohho, Manzini and Shiselweni Regions. Masters' Thesis, University of Swaziland. Luyengo, Swaziland. https://doi.org/10.5296/rae.v6i3.6045

Simelane, L. (2014). Participation of the Previously Landless in Farmer Companies under LUSIP Project in Swaziland. Masters' Thesis, University of the Witwatersrand. Johannesburg, RSA.

Singh, A. S., \& Masuku, M. B. (2014). Sampling Techniques and Determination of Sample Size in Applied Statistics Research: An Overview, International Journal of Economics, Commerce and Management, 2(11), 1-22.

Supaporn, P. (2015). Determinants of Technical Efficiency of Sugarcane Production Among small holder Farmers in Lao PDR. American Journal of Applied Sciences, 12(9), 644-649. https://doi.org/10.3844/ajassp.2015.644.649

Swaziland Sugarcane Association (SSA), (2015). Integrated Annual Report 2014/2015, 5-33.

Terry, A., \& Ogg, M. (2016). Restructuring the Swazi Sugar Industry: The Changing Role and Political Significance of Smallholders. Journal of Southern African Studies, 2-19. https://doi.org/10.1080/03057070.2016.1190520

Tew, C. (2010). Importance of Agritourism for Agripreneur Goal Accomplishment. Masters' Thesis, University of Missouri. Missouri.

Thabethe, L. S., Mungatana, E., \& Labuschagne, M. (2014). Estimation of Technical, Economic and Allocative Efficiencies in Sugarcane Production in South Africa: A Case of Mpumalanga Growers. Journal of Economics and Sustainable Development, 5(16), 86-95.

\section{Copyright Disclaimer}

Copyright for this article is retained by the author(s), with first publication rights granted to the journal.

This is an open-access article distributed under the terms and conditions of the Creative Commons Attribution license (http://creativecommons.org/licenses/by/4.0/). 